\title{
養鰻池の水変りに関する研究一XIV。
}

カドッボワムシの異常増殖を伴つた水変り

(插図 $1 \sim 3$ )

\section{伊藤隆, 岩井壽夫}

Studies on the "Mizukawari" in eel-culture ponds. XIV.

On the "Mizukawari" phenomenon accompanied with the explosive occurrence of Brachionus quadridentatus

By Takashi Ito and Toshio IwAI

\begin{abstract}
1 緒言
津市北部の養鰻池群の池水は相当の塩分它含有し， $\alpha$-中戴性汽水に属する。これらの 養鰻池群における “水変り”に法汽水産輪虫 Brachionus plicatilis O.F. MüLLER の大 増殖が伴つている場合が大部分である（伊藤，岩井 1956a；1958a，c）。こ机らの水変り は輪虫の異常增殖とその著しい micron-algae の捕食作用が有力な原因であることを一連 の実験的研究によつて明らかにした（伊藤 1955a，b; 伊藤，岩井 1956b; 伊藤 1957a ; 伊藤, 岩井 1957b).

ここに報告する水変りは, 津市南部米津地区の山出養魚場第 3 号養鰻池 $\left(\mathrm{Y}_{3}\right.$ 池と略称す る）で炤和 32 年 5 月中旬に見られたものである。この水変りには淡水産輪虫 Brachionus quadridentatus var. cluniorbicularis の大増殖が伴つた. 本輪虫の異常増殖を伴つた水 変りは，従来報告された例炎知らない。ここにその水変りの等態を報告する次第である.

本調查に種々の便宜と協力を与えられた池の所有者, 山出榮松氏に深茥の謝意を表しま す.なおこの研究の費用の 1 部は昭和 32 年度文部省科学研究費に仰いだ。

\section{2 池の概沅並に調査方法}

$\mathrm{Y}_{3}$ 池ほ津市米津地区, 相川の北岸に位する面積約 $1.9 \mathrm{a}$, 水深約 $30 \mathrm{~cm}$, 砂質の浅いシ ラス養成池で, 当時約 15000 尾のシラスウナギが放養さ机ていた. 池水の塩分は Cl 5.1

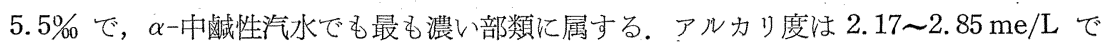
あつた。

観測は炤和 32 年 4 月下旬方ら 5 月 30 日に亘り, 19 回行い，観測時刻は原則として4前 8
\end{abstract}




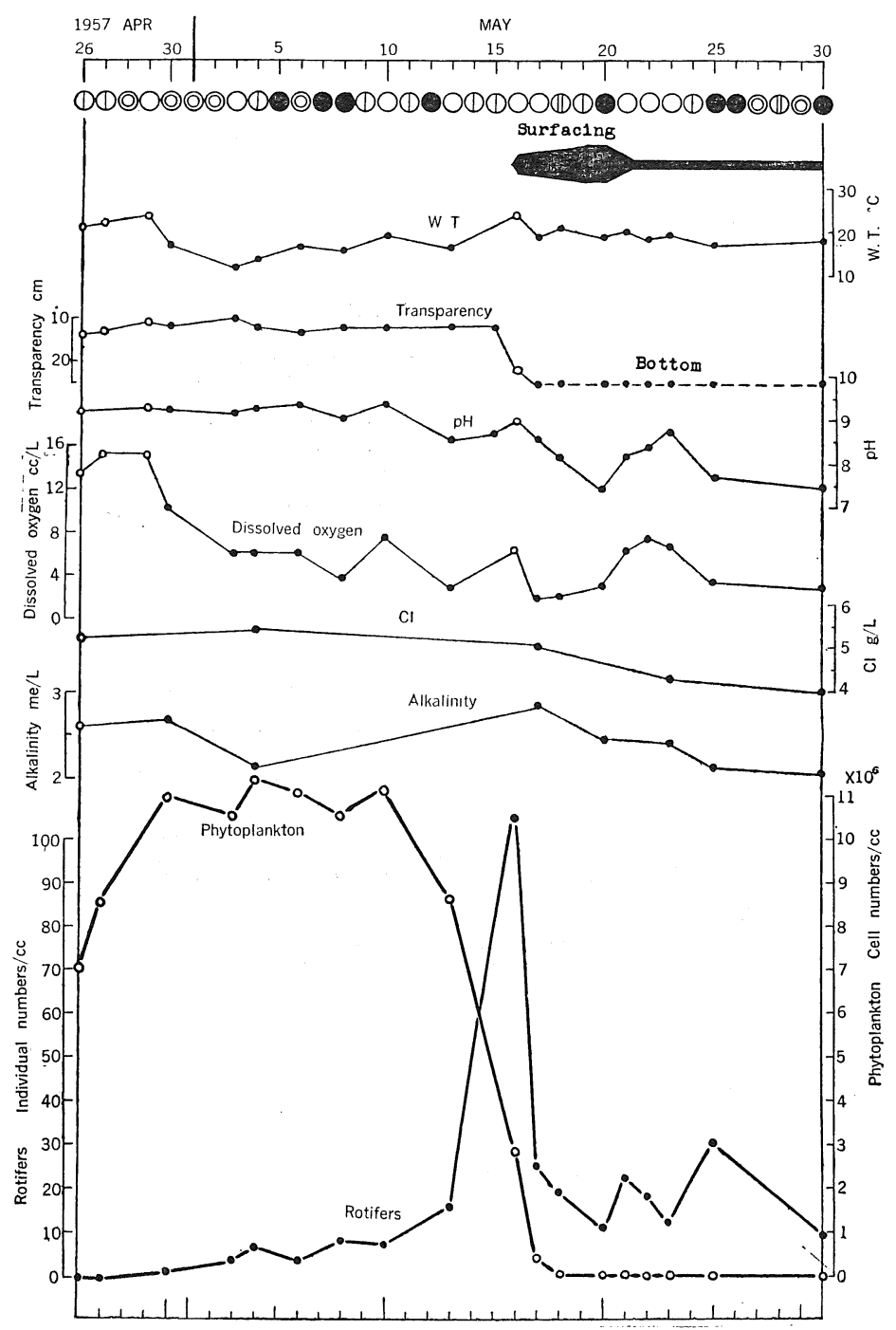

Fig. 1 The daily change of some physico-chemical factors, phytoplankton, rotifers, and the "Mizukawari" phenomenon in a eel-culture pond (area $1.9 \mathrm{a}$, depth $30 \mathrm{~cm}, \mathrm{Cl} 5.1 \sim 5.5 \%$ ) in the southern vicinity of Tsu City, Mie Prefecture. Middle Japan, from April to the end of May, 1957. 
1959j

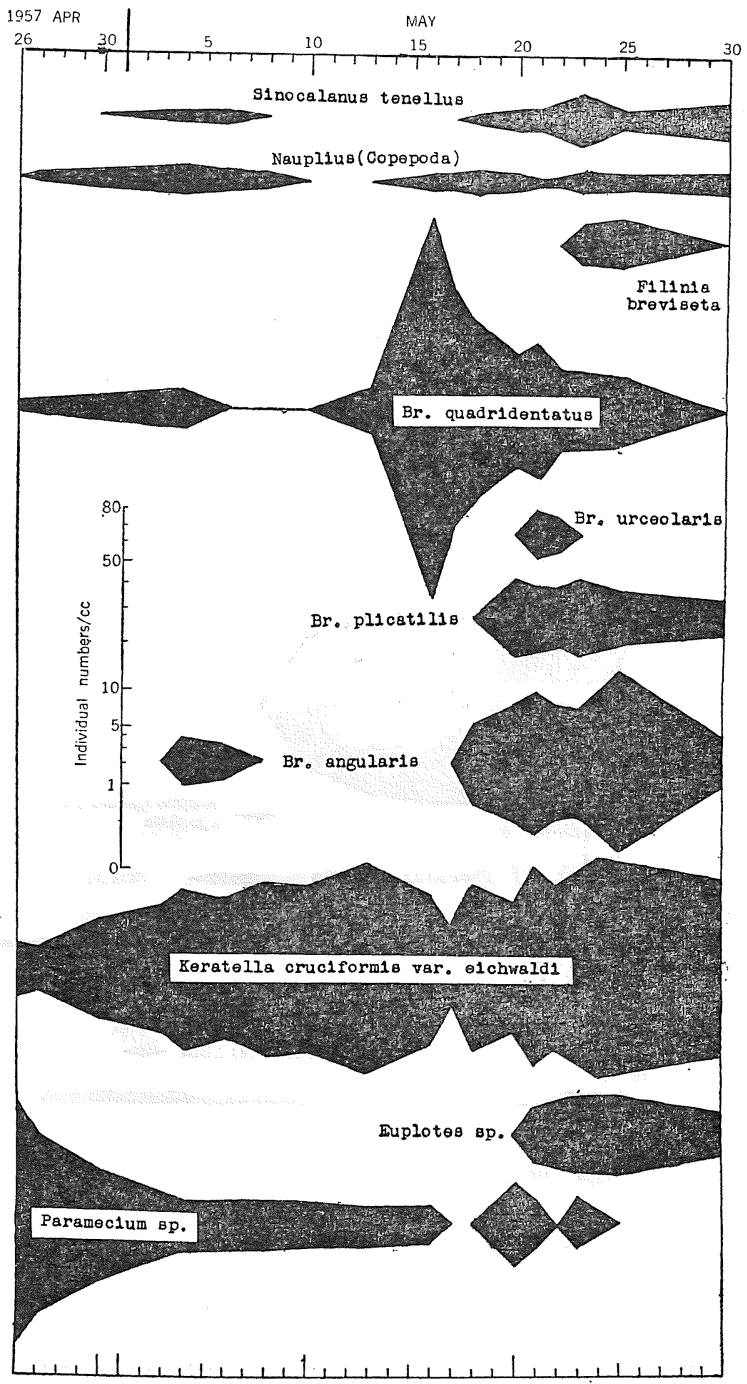

Fig. 2 The daily change of zooplankters in the eel-culture pond. The figures are illustrated by LoHMANN's spherical curve method.

時前後で，比較のために午後行つたものもある．透明度は中村式透明度板を用い，水色は 肉眼で測定した，水質は表㐿水のみについて， $\mathrm{pH}$ は比色法により，溶存酸素は WINkLER 
の沃度滴定法により，アルカリ度は B.C.P. 学指示薬として N/100 HCl で， Cl は硝酸 銀滴定の常法によつて夫々測定した。

動物プランクトンの定量は，個体数計数法によつた．輪虫類並に繊毛虫類は主として約 $100 \mathrm{cc}$ の酸素㼚に採水し，フォルマリンで固定沈澱させ，2１0cc に濃縮し，その中から $0.5 \mathrm{cc}$ を抽出し，計数盤にとり，その中に含まれる全個体を種類別に計数し，池水 $1 \mathrm{~L}$ あ たりの個体数を算出した。橈脚類その他のプランクトン甲殼類は，表層水 $10 \mathrm{~L}$ を No. XX 16 のプランクトンネットで瀘過したものについて，酸素㼛の場合と同様の方法で計数 し，これも池水 $1 \mathrm{~L}$ あたりの個体数を算出した，輪虫並に繊毛虫密度が小さいときは，こ のネットプランクトンの資料安加味した。

植物プランクトンの定量には細胞数計数法を適用した。表層水を酸素㼛に採水，フォル

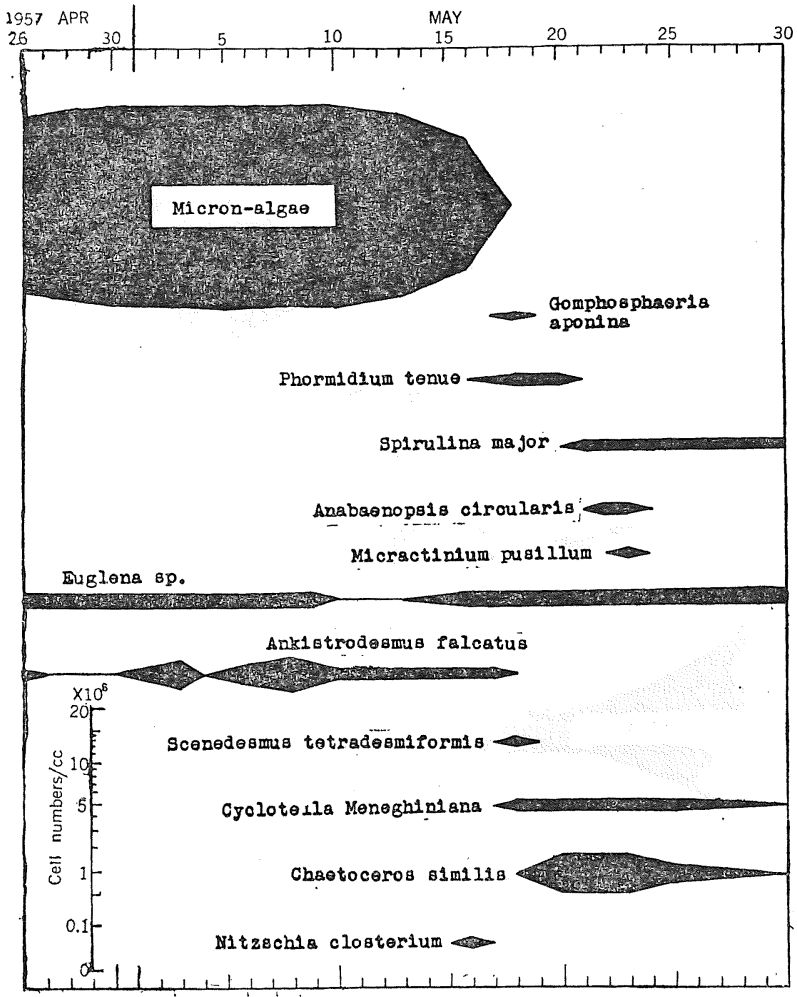

Ffg. 3 The daily change of phytoplankton in the eel-culture pond. The figures are illustrated by LoHmans's spherical curve method. 
マリン定加光て約 7 １0日間静置し，完全に沈積させた後，上澄をサイフォンで寨却し，

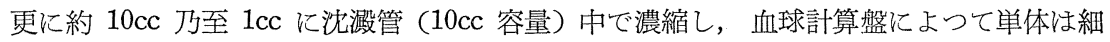
胞数として，群体を形成するものは colony 数として $1 \mathrm{cc}$ あたりの価を算出した.

動物並に植物プランクトンの定量結果は LOHMANn の球曲線法によつて Figs. 2 3 示した。

\section{3 観 測 結 果}

\section{A）シラスウナギの状態}

餌付は 5 月15日まで良好であつたが，16日から飰付不良となり，19２0日の両日の朝に はシラスウナギは池縁の浅所に集り，鼾上げした。鼻上げは 21 日から止えだが，餌付は 不良で，この状態が 30 日宋で継続した。 30 日には全池水堂排水し，シラスウナギは隣接 した $\mathrm{Y}_{2}$ 池に移した (Fig. 1).

B）動物プランクトン

4 月下旬から汽水産輪虫 Keratella cruciformis var. eichwaldi が徐々に増殖した が，15１6日頃には一時的に減少した。これとは逆に淡水産輪虫のBr.quadridentatus var. cluniorbicularis 吕爆発的に增殖し，16日に最大密度 106個体/cc に達し，その後急 激に減少した。乙の減少後 Br. urceolaris, Br. plicatilis, Br. angularis 等も出現増 殖したが，大きい密度には達しなかつた。橈脚類の Sinocalanus tenellus とその nauplius 活輪虫の異常増殖時には殆えぞ消滅した。 この点はBr. plicatilis の大増殖を伴つ た水変りの場合と一致する (Fig. 2).

C) 植物プランクトン

水変り前の $\mathrm{Y}_{3}$ 池の植物プランクトンの優占種は種名不詳の micron-algae で, 殆えぞ この単一種より構成され，その密度は約 $11 \times 10^{6}$ 細胞/cc であうた。 この micron-algae の細胞の直径は 2 3 3 である。この micron-algae は 5 月13日頃から輪虫の増殖とは逆 に急激に減少しはじめ，16日には約 $1 / 4$ に，17日には約 1/20 に減少し，18日には痕跡 程度となつた，20日頃から硅藻類のChaetoceros similis が一時的に稍々増殖したが，植 物プランクトンの大増殖は 5 月 30 日まで見られなかつた。水変り後におけるChaetoceros similis の一時的增殖は多くの津附近の水変りの場合と一致する. Chaetoceros similis 水変りの回復性の 1 指標であることは既に指摘した（伊藤，岩井 1958a，b，c）.

D) 水 質

5 月10日前後までは micron-algae がよく增殖し, 池水は緑色を呈し, 透明度は10 12 $\mathrm{cm}, \mathrm{pH}$ は 9 以上, 溶存酸素量は 5 月上旬から徐々に減少の傾向が見られるが, 朝 8 時 頃でも $4 \mathrm{cc} / \mathrm{L}$ 以上を示している，乙かし5月15１6日頃から，水色は褐色系が加かり， 
緑褐色となり，18日には黄褐色となり，20日には殆えど透明に近くなつた。 この状態は 5 月末まで続いた。 $\mathrm{pH}$ も低下し最低 7.4 は20日に見られた。 この時期は輪虫の最大密度を 過ぎ，整死した時期に相当する。溶存酸素量も16〜18日には最低 $2 \mathrm{cc} / \mathrm{L}$ を示した．早朝 には更に減少したものと思わ秃る。21 23日に溶存酸素が一時的に増加し，約 $7 \mathrm{cc} / \mathrm{L}$ を 示し，また $\mathrm{pH}$ も 8.1 8.7 となつたが，乙れは前記のChaetoceros similis の一時的増 殖と一致しているので，この硅藻の炭酸同化作用によることは明らかであろう (Fig. 1).

\section{4 要約}

5 月16日から20日に亘る $\mathrm{Y}_{3}$ 池の水変り時には，消費者としての輪虫類，Brachionus quadridentatus が爆発的に増殖し，逆に生産者としての micron-algae が急激に減少し， 3〜4 日のうちに殆えぞ消滅した。また水色は緑色から褐色系を経て透明に近くなり，透 明度も急激に増大し，池水の $\mathrm{pH}$ 並に溶存酸素も減少し，ウナギは鼻上げ，慨付不良等の 異常現象を現わした。 この水変りの実態は汽水産輪虫のBr.plicatilis の異常增殖安伴つ た水変りのそれとよく一致する。 そしてての $\mathrm{Y}_{3}$ 池の水変りは淡水産輪虫 Br. quadridentatus var. cluniorbicularis の爆発的增殖とその著しい micron-algae の捕食作用吕 原因であることほ他の実験的研究（伊藤，岩井 1957b；伊藤，未発表）の結果から見て明 らかであろう。また水変り前池涾の溶存酸素量が次第に減少する傾向があるので，植物 プランクトンの優占種 micron-algae の生理機能も衰えていたのではないかと考元られる.

引用文 献

伊藤 隆：養鰻池の水変りに関する研究 (I). Brachionus plicatilis によるプランクト ン植物の捕食作用（水変りの 1 因として）. Rep. Fac. Fish. Pref. Univ. Mie, 2, 1, 162 167, 1955a.

伊藤 隆：養鰻池の水変りに関する研究 (II). Brachionus plicatilis による水変りにお ける $\mathrm{pH}$ 並に $\mathrm{O}_{2}$ の変化. Ibid., 2, 1, 168 177, $1955 \mathrm{~b}$.

伊藤 隆, 岩井寿夫 : 養鰻池の水変りに関する研究 (IV). 水変り池飞おける Brachionus plicatilis の垂直分布. Ibid., 2，2，325３34，1956a.

伊藤 隆：養鰻池の水変りに関する研究 $(\mathrm{V})$. Brachionus plicatilis による水変り過程 における水質の変化. Ibid., 2，2，335 346，1956b.

伊藤 隆: 養鰻池の水変りに関する研究 $(\mathrm{VI})$. Brachionus plicatilis の增殖とプランク トン植物量との関係. Ibid., 2，3，502～508，1957a.

伊藤 隆，岩井寿夫：養鰻池の水変りに関する研究 (VII). Brachionus plicatilis の捕食

作用とプランクトン植物の大きさ. Ibid., 2，3，509〜516，1957b.

伊藤 隆，岩井寿夫：養鰻池の水変りに関する研究 $(V I I I)$ ，津市江戸橋附近の 6 面の養鰻 
池における昭和 30 年中の水変り. Ibid., 3, 1，122～158, 1958a.

伊藤 隆, 岩井寿夫 : 養鰻池の水変りに関する研究 (IX). 冬期における水変り. Ibid., 3, 1, 159 169, 1958b.

伊藤 隆，岩井寿夫：養鰻池の水変りに関する研究 (XII). プランクトン動物の動きと水

変り. Ibid., 3, 1, 193〜208, 1958c.

伊藤 隆：水変りの原因説について。「鰻」，創刊号，7～11，1958d.

伊藤 隆：汽水産輪虫 Brachionus plicatilis O.F. MüLLER の増殖機構.（未発表）

\section{S U M M A R Y}

In an eel-culture pond of mesohaline brackish water (area $1.9 \mathrm{a}$, depth $30 \mathrm{~cm}$, C1 5.1 5.5\%) in the southern vicinity of Tsu City, Mie Prefecture, there was observed a marked surfacing phenomenon of cultured eels during the period from 16th to 20th of May, 1957.

At that time, a freshwater rotifer, Brachionus quadridentatus var. cluniorbicularis increased explosively (Figs. 1 2), while the micron-algae which were the dominant species of phytoplankton quite disappeared (Figs. 1 and 3). The colour of pond-water gradually changed from green to yellowish brown, and then quite discoloured; and the transparency suddenly became higher, and the dissolved oxygen and the $\mathrm{pH}$-values diminished (Fig. 1).

This so-called "Mizukawari" phenomenon seems to be due to an explosive increase of $\mathrm{Br}$. quadridentatus which may devour micron-algae.

（著者：伊藤 隆，岩井寿夫，三重県立大学水産学部陸水学研究室，Takashi， ITo and Toshio IWAI; Limnological Laboratory, Faculty of Fisheries, Prefectural University of Mie) 